\title{
A review of Tuta absoluta (Lepidoptera: Gelechiidae) host plants and their impact on management strategies
}

\author{
Asma Cherif, François Verheggen \\ University of Liege - Gembloux Agro-Bio Tech. Terra. Avenue de la Faculté d'Agronomie, 2B. BE-5030 Gembloux \\ (Belgium). E-mail: fverheggen@uliege.be
}

Received 7 May 2019, accepted 16 September 2019, available online 23 October 2019.

This article is distributed under the terms and conditions of the CC-BY License (http://creativecommons.org/licenses/by/4.0)

Introduction. Tuta absoluta is one of the most harmful insect pests of tomato crops worldwide. While its host plants mainly include Solanaceae species, recent studies suggest that it can lay eggs and develop on a wider range of wild and cultivated plants. No complete list of host plants based on available scientific data exists. Such information is important for those who aim at performing integrated management strategies against this pest, especially when it comes to identify host reservoirs where the species can survive between harvests or avoid insecticide exposure.

Literature. We identified cultivated and non-cultivated plant species belonging to Solanaceae, Amaranthaceae, Euphorbiaceae, Cucurbitaceae, Geraniaceae, Fabaceae, Asteraceae and Malvaceae that allow partial or complete egg-imago development. Among them, we found out that most non-Solanaceous plants serve as oviposition sites only (with no larval development possible), and a few of them allow partial life cycle (causing late instars to die prematurely). We also identified a strong cultivar-dependence in the most common cultivated plant species including tomato and potato.

Conclusions. We discuss the potential of resistant and genetically modified tomato cultivars, plant chemical compounds and fertilization as components of integrated control strategies of T. absoluta.

Keywords. Tomato leafminer, host range, Integrated Pest Management (IPM).

Une revue des plantes hôtes de Tuta absoluta (Lepidoptera: Gelechiidae) et leur impact sur les stratégies de gestion Introduction. Tuta absoluta est l'un des ravageurs les plus nuisibles des cultures de tomate dans le monde. Bien que ses plantes hôtes incluent principalement des espèces de Solanacées, des études récentes suggèrent que cet insecte peut pondre et se développer sur une large gamme de plantes sauvages et cultivées. Il n'existe pas de liste complète des plantes hôtes basée sur les données scientifiques disponibles. Ces informations sont importantes pour ceux qui souhaitent mettre en œuvre des stratégies de gestion intégrée contre cet organisme nuisible, notamment lorsqu'il s'agit d'identifier les hôtes réservoirs, où l'espèce peut survivre entre les récoltes ou éviter l'exposition à des insecticides.

Littérature. Des plantes sauvages et cultivées appartenant aux Solanacées, Amarantacées, Euphorbiacées, Cucurbitacées, Géraniacées, Fabacées, Astéracées et Malvacées, permettant un développement œuf-imago partiel ou complet, ont été identifiées. La plupart des plantes non-Solanacées servent seulement comme un site d'oviposition (sans développement larvaire possible) et quelques-unes permettent un cycle de vie partiel (mortalité prématurée des derniers stades larvaires). Une forte dépendance vis-à-vis des cultivars pour la plupart des plantes cultivées telles que la tomate et la pomme de terre a été identifiée. Conclusions. Nous discutons du potentiel des variétés de tomates résistantes ou génétiquement modifiées, des composés chimiques des plantes et de la fertilisation comme composante de stratégies de lutte intégrée contre T. absoluta.

Mots-clés. Mineuse de la tomate, gamme des plantes hôtes, gestion intégrée des ravageurs.

\section{INTRODUCTION}

The South American tomato pinworm Tuta absoluta (Meyrick) (Lepidoptera: Gelechiidae) is an invasive pest considered as one of the major threats to tomato cultivations worldwide (Desneux et al., 2010; Biondi et al., 2018). Tuta absoluta originates from Peru and started disseminating outside South America in the 2000s (Campos et al., 2017). The species is now infesting tomato crops in the Caribbean, Africa, Europe and Asia, where it has rapidly been considered a priority target pest (Desneux et al., 2011; Biondi 
et al., 2018; Mansour et al., 2018; Verheggen \& Fontus, 2019). In this species, larvae feed on the mesophyll of aerial parts of tomato plants, mining the leaves, stems, apices, flowers and fruits (Miranda et al., 1998), leading to heavy losses, especially in cases where management strategies are not efficiently developed (Desneux et al., 2010; González-Cabrera et al., 2011; Caparros Megido et al., 2013b).

The species is mainly associated with tomato plants, but recent studies suggest that it can oviposit and develop on a wider range of cultivated and wild plant species. Solanaceae are the most preferred hosts, and include tomato (Solanum lycopersicum L.), potato (Solanum tuberosum L.), eggplant (Solanum melongena L.), pepino (Solanum muricatum Aiton) and black nightshade (Solanum nigrum L.). With the increasing attention this pest has been receiving in the last decade, additional host plants were identified, including the common bean (Phaseolus vulgaris L.) and the European bindweed (Convolvulus arvensis L.) (Portakaldali et al., 2013; Bawin et al., 2016; Ingegno et al., 2017a; Ingegno et al., 2017b; EPPO, 2019). To the authors' best knowledge, no complete list of host plants has been built from the available scientific data, including host plant species allowing partial development cycle. Such information is important for those who aim at performing integrated management strategies against this pest, especially when it comes to identify host reservoirs where the species can survive between harvests or avoid insecticide exposure.

\section{METHODOLOGY}

To identify the relevant scientific literature related to Tuta absoluta host plant suitability, all terms potentially related to these words were listed. These terms were then included in a single query, as follows: ("Tuta absoluta" OR "Phthorimaea absoluta" OR "Gnorimoschema absoluta" OR "Scrobipalpula absoluta" OR "Scrobipalpuloides absoluta" OR "tomato leafminer" OR "tomato borer" OR "tomato pinworm" OR "tomato leaf miner" OR "South American tomato pinworm") AND (plant OR variety OR cultivar) AND (oviposition OR location OR development OR "life cycle" OR fitness OR "life history traits"). The composed terms were placed between quotation marks so that the entire term was considered. An asterisk was used to include all words that have a common core.

This research was completed between October and November 2018 by introducing the query into the following search engines: Scopus ${ }^{\circledR}$ (Elsevier), PubMed®, and Google Scholar ${ }^{\circledR}$. The resulting references were then selected or rejected based on the abstracts of the published papers, keeping research dealing with the laboratory or field evaluation of some
T. absoluta life history traits. Papers published in nonpeer reviewed journals were not considered.

\section{HOST PLANT LOCATION}

Plant volatile organic compounds guide the host finding behaviour of T. absoluta females and allow them to discriminate between potential hosts (Caparros Megido et al., 2014). Using wind tunnel assays, Proffit et al. (2011) demonstrated that T.absoluta females significantly oriented their flight toward cultivated tomato Solanum lycopersicum over wild tomato Solanum habrochaites, the latter being a less suitable host for larval development. In other wind tunnel assays, T.absoluta females preferred flying toward tomato plants rather than potato plants (Caparros Megido et al., 2014), but no preference was highlighted between S. nigrum and S. tuberosum (Bawin et al., 2015). These results were comforted by the very similar volatile organic compound profile of both plants. The volatile profile of these two plant species, however, exhibited quantitative and qualitative differences with other solanaceous plants, Atropa belladonna and Datura stramonium, which were much less attractive to T. absoluta females (Bawin et al., 2015). Recently, Ingegno et al. (2017b) suggested that T.absoluta females prefer laying eggs (in decreasing order) on tomato S.lycopersicum (cv. Marmande), European black nightshade S. nigrum, eggplant S.melongena (cv. Bellezza nera), zucchini Cucurbita pepo (cv. Nero di Milano) and potato S. tuberosum (cv. Villastellone).

Once a plant is selected as a potential host for egg laying, T. absoluta females preferentially select the underside of apical tomato leaves, that are characterized by a lower calcium content (Torres et al., 2001; Leite et al., 2004; Proffit et al., 2011; Cherif et al., 2013). Oviposition was then associated with a modification of the terpene emissions of the selected host plant (Anastasaki et al., 2015).

\section{HOST PLANT SUITABILITY}

The main host of T.absoluta is cultivated tomato: the global fitness of this insect species is higher on this particular host compared to other plant species, according to all laboratory experiments performed to date (Negi et al., 2018; Cherif et al., 2019) (Table 1). Nevertheless, many Solanaceae species allow T. absoluta feeding, development and reproduction. Numerous studies highlighted the suitability of potato (S.tuberosum), eggplant (S. melongena), and pepino (S. muricatum) for T. absoluta development (Pereyra \& Sánchez, 2006; Caparros Megido et al., 2013a; Negi et al., 2018; Cherif et al., 2019). Ingegno et al. (2017a) 


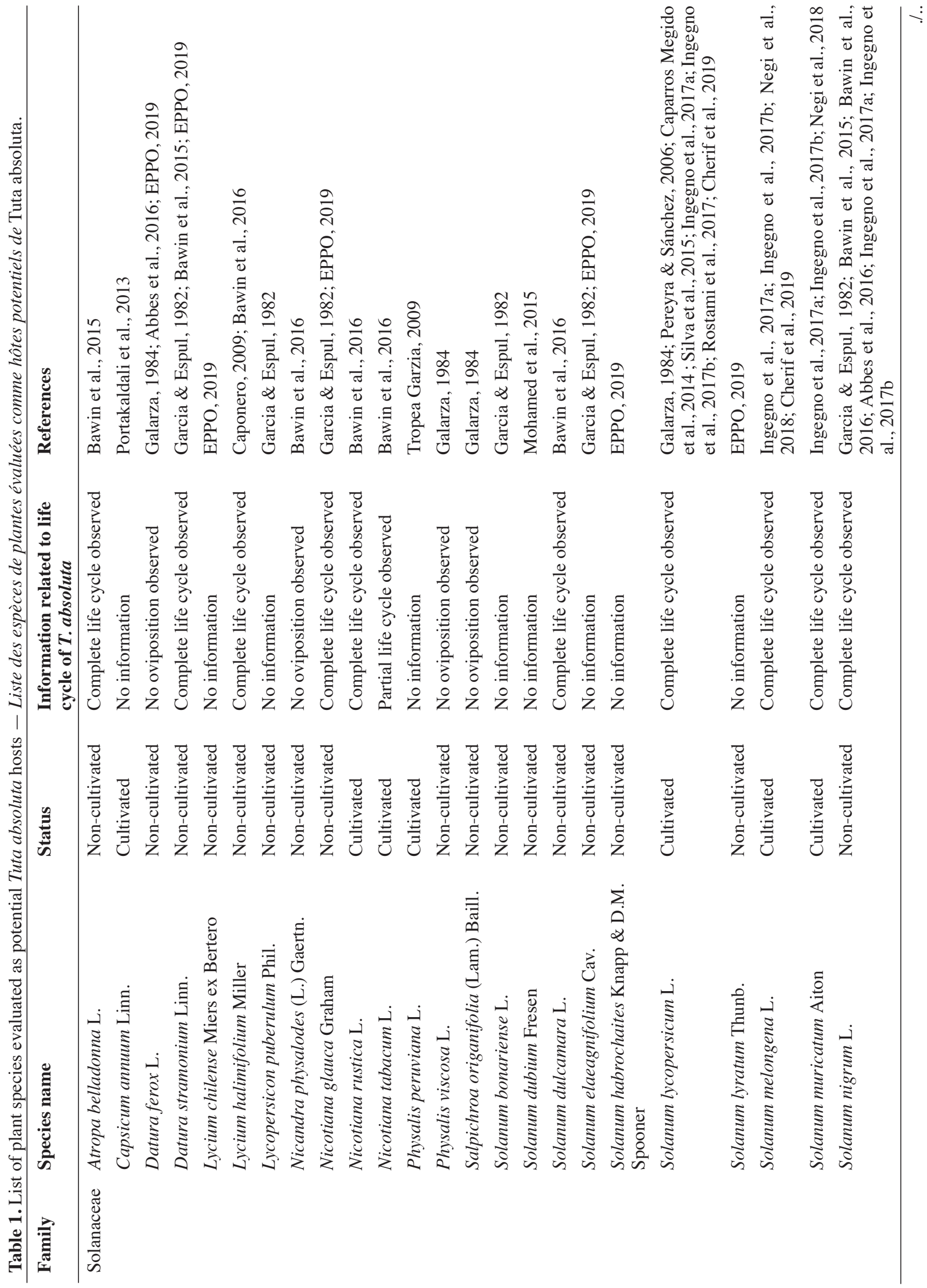


Tuta absoluta host plants

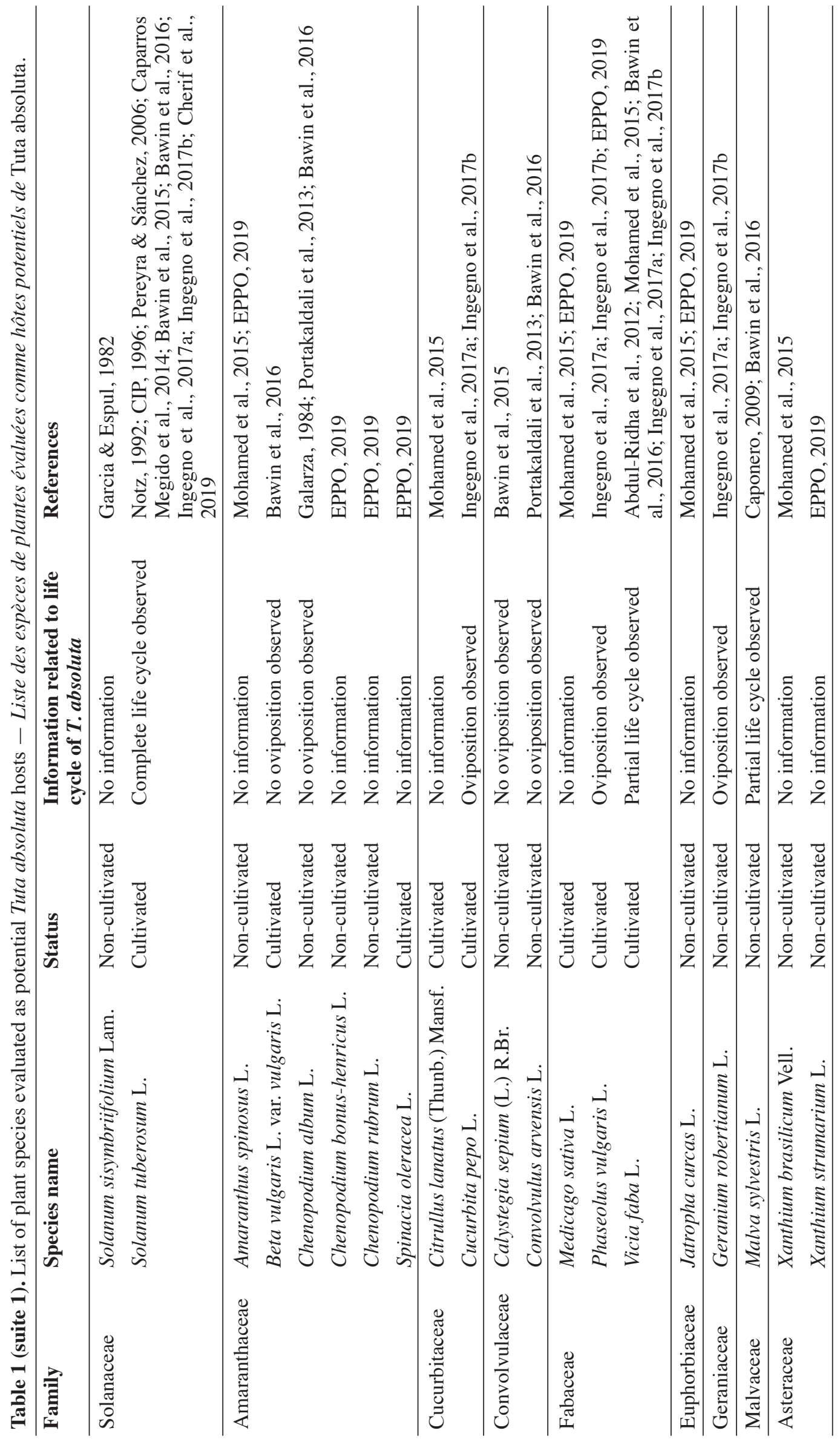


found no fitness difference between individuals reared on S. lycopersicum and S. nigrum. Garcia \& Espul (1982) showed that T. absoluta was able to complete its development on some wild Solanaceae species including S. nigrum, S. elaeagnifolium, Lycopersicum puberulum, Datura ferox, D. stramonium and Nicotiana glauca. In particular, the tomato leafminer showed the ability to overwinter, yet at low population density, on winter potato and S. nigrum (Cocco et al., 2015). Alternative hosts in winter may therefore represent a source of re-infestation for spring-summer tomato crops. Finally, Galarza (1984) showed that no eggs were laid by T.absoluta on several Solanaceous species, including Salpichroa origanifolia, D.ferox and Physalis viscosa. Datura stramonium did not allow T.absoluta to complete its life cycle (Bawin et al., 2015; Abbes et al., 2016).

Our literature survey also highlighted plants belonging to Amaranthaceae, Cucurbitaceae, Fabaceae, Euphorbiaceae, Malvacea and Asteraceae, which are reported as alternative hosts for this pest (Table 1). Convolvulaceae are not suitable alternative hosts for T. absoluta: no oviposition was observed on Calystegia sepium and Convolvulus arvensis (Bawin et al., 2016). Also, T. absoluta does not oviposit on Beta vulgaris vulgaris and Chenopodium album, belonging to Amaranthaceae (Bawin et al., 2016). Finally, T. absoluta could not develop on other plant species such as Geranium robertianum and C.pepo (Ingegno et al., 2017b).

Suitability of host plants to T. absoluta development may be linked to its oviposition behaviour which may influence the larval survivability, given that most lepidopteran larvae cannot migrate to alternative host plants (Awmack \& Leather, 2002; Gripenberg et al., 2010). Various factors may influence the oviposition site selected by the leafminer, including the larval host plant experience (Caparros Megido et al., 2014), the conspecific infestation level (Bawin et al., 2014; De Backer et al., 2015) and parasites (Bawin et al., 2014).

\section{HOST PLANTS AND TUTA ABSOLUTA CONTROL}

Using tolerant cultivars in plant breeding programs may reduce the use of chemical insecticides as well as problems of resistance to many active ingredients (Gharekhani \& Salek-Ebrahimi, 2014). In search for tolerant tomato cultivars, T. absoluta life history traits were compared on different cultivars during field and laboratory assays (Table 2). Several studies made conclusions based on the absence of fitness differences among the tested tomato cultivars: the intrinsic rate of increase, net reproductive rate, and mean generation times were similar in T.absoluta individuals reared on the cultivars 'Falkato', 'Isabella' and 'Grandella' (Rostami et al., 2017). However, many other studies showed differences among the tested cultivars (Table 2). Susceptible tomato cultivars tested under laboratory or field conditions were characterized by a high number of mined (with or without larvae) leaves, stems or fruits, as well as a better suitability for egg-laying (Oliveira et al., 2009; Cherif et al., 2013; Khederi et al., 2014; Darbain et al., 2016; Sohrabi et al., 2016a; Sohrabi et al., 2016b; Allache et al., 2017; Ghaderi et al., 2017). Tomato cultivar 'Bravo' is commonly classified as one of the most susceptible cultivars, and was shown to be a better host plant than cultivar 'Tex 317': the latter led to a longer development time and a lower emergence rate (Silva et al., 2015). The net reproductive rate as well as the intrinsic rate of population growth were both higher on 'Bravo' than on 'Tex 317'. Larvae feeding on the 'Valouro' cultivar, classified as highly susceptible to T.absoluta infestation, showed the lowest proteolytic and amylolytic activity and reached the highest body weight $(3.42 \mathrm{mg})$ compared to the 'Korral' cultivar (Shahbaz et al., 2017). Sadeghinasab et al. (2017) indicated that $\mathrm{Km}$ and Vmax values for $\alpha$-amylase, the specific activity of $\alpha$-/ $\beta$-glucosidases and $\alpha / \beta$-galactosidases, obtained for $T$. absoluta fourth instar larvae differ among tested tomato cultivars ('Kingston', 'Riogrande', 'Super Luna', 'Super Chief', 'Super strain B' and 'Calj'). They reported that the 'Kingston' cultivar could be considered as the least suitable host for T. absoluta development, since larvae showed lowest carbohydrase activities.

Tuta absoluta cultivar resistance is likely associated with the diversity and abundance of glandular trichomes (Campos et al., 2009; Khederi et al., 2014; Shahbaz et al., 2017). The length and density of glandular trichomes are negatively correlated with T.absoluta damage (Darbain et al., 2016). Sohrabi et al. (2016b) suggested that the high density of leaf trichomes present in three cultivars (cvs. 'Berlina', 'Zaman' and 'Golsar') tested under field conditions could be one of the possible causes of resistance to the tomato leafminer. In Lycopersicon hirsutum, the increase of glandular trichome density, especially the abundance of 2-TD, was linked with the reduction of the larval development rate and survival of T.absoluta (Leite et al., 1999a; Leite et al., 1999b; Leite et al., 2001). Khederi et al. (2014) found that, under greenhouse conditions, the most infested tomato genotypes (Mobil and Cal J N3) displayed the lowest IV and VI trichome style ranks of leaf blade, vein and domatia (glandular trichomes). De Oliveira et al. (2012) confirmed that genotypes with higher densities of glandular trichomes had higher resistance than the susceptible controls, with the strain BPX-367D-238-02 being particularly notable in its resistance. However, glandular trichomes 
Table 2. List of tolerant and susceptible tomato cultivars to Tuta absoluta damages - Liste des cultivars de tomate tolérants et sensibles aux dégâts de Tuta absoluta.

\begin{tabular}{|c|c|c|c|c|}
\hline Assays & & Tolerant cultivars & Susceptible cultivars & Reference \\
\hline \multirow[t]{8}{*}{ Field } & \multirow[t]{4}{*}{ Open field } & $\begin{array}{l}\text { 'Shams' } \\
\text { 'Chebli' }\end{array}$ & 'Ferrinz' & Cherif et al., 2013 \\
\hline & & $\begin{array}{l}\text { 'Raha' } \\
\text { 'Quintini' } \\
\text { 'ES9090 F' }\end{array}$ & & Sohrabi et al., 2016a \\
\hline & & $\begin{array}{l}\text { 'Berlina' } \\
\text { 'Golsar' } \\
\text { 'Poolad' } \\
\text { 'Zaman' } \\
\text { 'Golshan-616' } \\
\text { 'Sadeen-95' } \\
\text { 'Sadeen-21' }\end{array}$ & $\begin{array}{l}\text { 'Ps-6515' } \\
\text { 'Petoprid-5' } \\
\text { 'Matin' } \\
\text { 'Sandokan-F1' }\end{array}$ & Sohrabi et al., 2016b \\
\hline & & 'Logain' & $\begin{array}{l}\text { 'Alissa F1' } \\
\text { 'Super Strain B' }\end{array}$ & Darbain et al., 2016 \\
\hline & \multirow[t]{4}{*}{ Protected field } & $\begin{array}{l}\text { 'HGB-674' } \\
\text { 'HGB 497' }\end{array}$ & & Oliveira et al., 2009 \\
\hline & & $\begin{array}{l}\text { 'Rio Grande' } \\
\text { 'King ston' }\end{array}$ & $\begin{array}{l}\text { 'Mobil' } \\
\text { 'Cal JN3' }\end{array}$ & Khederi et al., 2014 \\
\hline & & $\begin{array}{l}\text { 'Korral' } \\
\text { 'CH Falat' }\end{array}$ & $\begin{array}{l}\text { 'Valouro' } \\
\text { 'Cal JN3' }\end{array}$ & Shahbaz et al., 2017 \\
\hline & & $\begin{array}{l}\text { 'Toufan' } \\
\text { 'Dawson' }\end{array}$ & 'Sahara' & Allache et al., 2017 \\
\hline \multirow[t]{3}{*}{ Laboratory } & & 'Tex 317' & 'Bravo' & Silva et al., 2015 \\
\hline & & $\begin{array}{l}\text { 'Primo Early' } \\
\text { 'Early Urbana' } \\
\text { 'Y' }\end{array}$ & 'Cal JN3' & Ghaderi et al., 2017 \\
\hline & & 'Kingston' & $\begin{array}{l}\text { 'Riogrande' } \\
\text { 'Super Luna' } \\
\text { 'Super Chief' } \\
\text { 'Super strain B' } \\
\text { 'Calj' }\end{array}$ & Sadeghinasab et al., 2017 \\
\hline
\end{tabular}

also reduce the fitness of biological control agents. Bottega et al. (2017) suggested that cultivars presenting high densities of glandular trichomes, especially those of type I and IV, could be antagonistic to biological control of T.absoluta by Podisus nigrispinus (Dallas) (Hemiptera: Pentatomidae) in tomato fields. Phytochemicals, which constitute approximately $90 \%$ of the type IV glandular trichromes secretion (Fobes et al., 1985), may play an important role in the resistance to T.absoluta (De Resende et al., 2006). De Resende et al. (2006) found that the resistance level increased with longer exposition time to the acylsugars contents in F2 and F2BC1 tomato plants derived from the interspecific crossing between L.esculentum 'TOM-584' and L. pennellii 'LA716', both in the field and in cage tests. They reported also that acylsugar contents seemed to be highly and negatively correlated with the traits related to the pinworm resistance.
Resistance mechanisms of plants against pests may be divided into two categories, namely antixenosis (non-preference of insect for plants) (Painter, 1951) and antibiosis (adverse physiological effects that occur in a pest after ingesting a plant) (Kogan, 1994). A recent study characterized the antixenosis and antibiosis resistance expression of genotypes in the Solanum section Lycopersicon (S. lycopersicum [Fiorentino, Naomi and Belle], S.habrochaites [RCAT030597, PI126446], S. chilense [INIABB79], S.peruvianum [RCAT031296, RCAT039874 and RCAT030403] and S. pimpinellifolium [PI390739]) against T. absoluta (Vitta et al., 2016). It has been demonstrated that the resistance-level characterization depends on the insect response; the genotype $S$. habrochaites (RCAT030597) presented more resistance by antibiosis, while $S$. chilense, considered as less preferred for oviposition, presented the highest larval survival (Vitta et al., 2016). 
Nitrogen inputs also impact the quality of a host for T. absoluta. At least three independent studies suggest that higher nitrogen fertilization enhances T.absoluta fitness (larval developmental rate, pupal weight, reproduction rate) (Larbat et al., 2015; Coqueret et al., 2017; Blazhevski et al., 2018). Recent studies reported that sub-optimal nitrogen supplies, water treatments or their interactions, negatively affect the survival and development of T. absoluta larvae on tomato plants (Han et al., 2014; Han et al., 2016).

\section{CONCLUSIONS}

Tuta absoluta is considered a key pest of tomato crops causing heavy yield losses worldwide. Great efforts have to be deployed in order to manage this pest by investigating its host range and developing eco-friendly and safe management tools. The host range and occurrence of T. absoluta in the landscape, especially on non-cultivated Solanaceous plants, is likely to influence the spread and abundance of the pest in the crop (Bawin et al., 2015; Cocco et al., 2015; Abbes et al., 2016). Cultural practices, including crop rotation with non-Solanaceous plants as well as removing and destruction of infested plants and weeds, may provide adequate management of the pest and help to reduce insecticide applications. Development of resistant tomato cultivars, by the transfer of resistance factors to commercial tomato cultivars, may be useful in pest management programs preconized against T. absoluta (Sohrabi et al., 2016b). The use of RNAi technology by producing transgenic plants that express dsRNA molecules should be reinforced (Camargo et al., 2016). Fertilization manipulation adopted in combination with biological control, host plant resistance and cultural practices may enhance the effectiveness of Integrated Pest Management packages used to control T.absoluta (Blazhevski et al., 2018).

\section{Acknowledgements}

The authors would like to thank emeritus Prof. Georges C. Lognay (Functional and Evolutive Entomology Department, ULg-Gembloux Agro-Bio Tech, Belgium) for his valuable contribution on an earlier version of the manuscript. Asma Cherif benefited from a Post-Doctoral Fellowship from the WBI (Wallonie-Bruxelles International.be) Excellence Scholarship Program.

\section{Bibliography}

Abbes K. et al., 2016. Bioassay of three solanaceous weeds as alternative hosts for the invasive tomato leafminer Tuta absoluta (Lepidoptera: Gelechiidae) and insights on their carryover potential. Afr. Entomol., 24, 334-342.
Abdul-Ridha M., Alwan S.L., Helal S.M. \& Aziz K.A., 2012. Alternative hosts of South American tomato moth Tuta absoluta (Gelechiidae: Lepidoptera) in some tomato farms of Najaf Province. Euphrates J. Agric. Sci., 4, 130-137.

Allache F., Demnati F. \& Houhou M.A., 2017. Population changes of Tuta absoluta (Gelechiidae) and fruit loss estimates on three tomato cultivars in greenhouses in Biskra, Algeria. Environ. Exp. Biol., 15, 201-208.

Anastasaki E. et al., 2015. Oviposition induced volatiles in tomato plants. Phytochem. Lett., 13, 262-266.

Awmack C.S. \& Leather S.R., 2002. Host plant quality and fecundity in herbivorous insects. Annu. Rev. Entomol., 47, 817-844.

Bawin T. et al., 2014. Infestation level influences oviposition site selection in the tomato leafminer Tuta absoluta (Lepidoptera: Gelechiidae). Insects, 5, 877-884.

Bawin T. et al., 2015. Could alternative solanaceous hosts act as refuges for the tomato leafminer, Tuta absoluta? Arthropod-Plant Interact., 9, 425-435.

Bawin T. et al., 2016. Ability of Tuta absoluta (Lepidoptera: Gelechiidae) to develop on alternative host plant species. Can. Entomol., 148, 434-442.

Biondi A., Guedes R.N.C., Wan F.H. \& Desneux N., 2018. Ecology, worldwide spread, and management of the invasive South American tomato pinworm, Tuta absoluta: past, present, and future (review). Annu. Rev. Entomol., 63, 239-258.

Blazhevski S., Kalaitzaki A.P. \& Tsagkarakis A.E., 2018. Impact of nitrogen and potassium fertilization regimes on the biology of the tomato leaf miner Tuta absoluta. Entomol. Generalis, 37, 157-174.

Bottega D.B. et al., 2017. Resistant and susceptible tomato genotypes have direct and indirect effects on Podisus nigrispinus preying on Tuta absoluta larvae. Biol. Control, 106, 27-34.

Camargo R.A. et al., 2016. RNA interference as a gene silencing tool to control Tuta absoluta in tomato (Solanum lycopersicum). PeerJ., 4, e2406v1, doi. org/10.7287/peerj.preprints.2406v1

Campos M.L. et al., 2009. Brassinosteroids interact negatively with jasmonates in the formation of antiherbivory traits in tomato. J. Exp. Bot., 60, 4347-4361.

Campos M.R. et al., 2017. From the Western Palaearctic region to beyond: Tuta absoluta ten years after invading Europe. J. Pest Sci., 90, 787-796.

Caparros Megido R., Brostaux Y., Haubruge E. \& Verheggen F.J., 2013a. Propensity of the tomato leafminer, Tuta absoluta (Lepidoptera: Gelechiidae), to develop on four potato plant varieties. Am. J. Potato Res., 90, 255-260.

Caparros Megido R., Haubruge E. \& Verheggen F.J., 2013b. Pheromone-based management strategies to control the tomato leafminer, Tuta absoluta (Lepidoptera: Gelechiidae). A review. Biotechnol. Agron. Soc. Environ., 17, 475-482. 
Caparros Megido R. et al., 2014. Role of larval host plant experience and solanaceous plant volatile emissions in Tuta absoluta (Lepidoptera: Gelechiidae) host finding behavior. Arthropod-Plant Interact., 8, 293-304.

Caponero A., 2009. Solanacee, rischio in serre. Resta alta l'attenzione alla tignola del pomodoro nelle colture protette. Colture Protette, 10, 96-97.

Cherif A., Mansour R. \& Grissa-Lebdi K., 2013. Biological aspects of tomato leafminer Tuta absoluta (Lepidoptera: Gelechiidae) in conditions of Northeastern Tunisia: possible implications for pest management. Environ. Exp. Biol., 11, 179-184.

Cherif A. et al., 2019. Elucidating key biological parameters of Tuta absoluta on different host plants and under various temperature and relative humidity regimes. Entomol. Generalis, 39, 1-7.

CIP, 1996. Major potato diseases, insects, and nematodes. $3^{\text {rd }}$ ed. Lima: Centro Internacional de la Papa.

Cocco A. et al., 2015. Seasonal phenology of Tuta absoluta (Lepidoptera: Gelechiidae) in protected and openfield crops under Mediterranean climatic conditions. Phytoparasitica, 43, 713-724.

Coqueret V. et al., 2017. Nitrogen nutrition of tomato plant alters leafminer dietary intake dynamics. J. Insect Physiol., 99, 130-138.

Darbain S. et al., 2016. Susceptibility of certain tomato cultivars to infestation with Tuta absoluta (Meyrick) (Lepidoptera: Gelechiidae) in relation to leaflet trichomes. Egypt. J. Agric. Res., 94, 829-840.

De Backer L. et al., 2015. Tuta absoluta-induced plant volatiles: attractiveness toward the generalist predator Macrolophus pygmaeus. Arthropod-Plant Interact., 9, 465-476.

De Oliveira C.M. et al., 2012. Resistance of tomato strains to the moth Tuta absoluta imparted by allelochemicals and trichome density. Ciênc. Agrotecnol., 36, 4552.

De Resende J.T.V. et al., 2006. Acylsuars in tomato leaflets confer resistance to the south American tomato pinworm, Tuta absoluta Meyr. Sci. Agric. (Piracicaba, Braz.), 63, 20-25.

Desneux N. et al., 2010. Biological invasion of European tomato crops by Tuta absoluta: ecology, geographic expansion and prospects for biological control. J. Pest Sci., 83, 197-215.

Desneux N., Luna M.G., Guillemaud T. \& Urbaneja A., 2011. The invasive South American tomato pinworm, Tuta absoluta, continues to spread in Afro-Eurasia and beyond: the new threat to tomato world production. J. Pest Sci., 84, 403-408.

EPPO, 2019. EPPO global database, https://gd.eppo.int/ taxon/GNORAB/hosts, (23/04/2019).

Fobes J.F., Mudd J.B. \& Marsden M.P.F., 1985. Epicuticular lipid accumulation on the leaves of Lycopersicon pennellii (Corr.) D'Arcy and Lycopersicon esculentum Mill. Plant Physiol., 77, 567-570.
Galarza J., 1984. Laboratory assessment of some solanaceous plants. Possible food-plants of the tomato moth Scrobipalpula absoluta (Meyr.) (Lepidoptera: Gelechiidae). IDIA, 421/424, 30-32.

García M.F. \& Espul J.C., 1982. Bioecology of the tomato moth (Scrobipalpula absoluta) in Mendoza, Argentine Republic. Rev. Investigaciones Agropecuarias, 17, 135146.

Ghaderi S., Fathipour Y. \& Asgari S., 2017. Susceptibility of seven selected tomato cultivars to Tuta absoluta (Lepidoptera: Gelechiidae): implications for its management. J. Econ. Entomol., 110, 421-429.

Gharekhani G.H. \& Salek-Ebrahimi H., 2014. Evaluating the damage of Tuta absoluta (Meyrick) (Lepidoptera: Gelechiidae) on some cultivars of tomato under greenhouse condition. Arch. Phytopathol. Plant Prot., 47, 429-436.

González-Cabrera J., Mollá O., Montón H. \& Urbaneja A., 2011. Efficacy of Bacillus thuringiensis (Berliner) in controlling the tomato borer, Tuta absoluta (Meyrick) (Lepidoptera: Gelechiidae). Biocontrol, 56, 71-80.

Gripenberg S., Mayhew P.J., Parnell M. \& Roslin T., 2010. A meta-analysis of preference-performance relationships in phytophagous insects. Ecol. Lett., 13, 383-393.

Han P. et al., 2014. Nitrogen and water availability to tomato plants triggers bottom-up effects on the leafminer Tuta absoluta. Sci.Rep., 4, 4455.

Han P. et al., 2016. Does plant cultivar difference modify the bottom-up effects of resource limitation on plantherbivorous insect interactions? J. Chem. Ecol., 42, 1293-1303.

Ingegno B.L., Candian V. \& Tavella L., 2017a. Behavioural study on host plants shared by the predator Dicyphus errans and the prey Tuta absoluta. Acta Hortic., 1164, 377-382.

Ingegno B.L. et al., 2017b. The potential of host plants for biological control of Tuta absoluta by the predator Dicyphus errans. Bull. Entomol. Res., 107(3), 340-348.

Khederi S.J. et al., 2014. Role of different trichome style in the resistance of Lycopersicon hirsutum genotypes to Tuta absoluta (Meyrick) (Lepidoptera: Gelechiidae). Ecol. Montenegrina, 1, 55-63.

Kogan M., 1994. Ecological aspects of pest management. In: Metcalf R. \& Luckmann W.H., eds. Introduction to insect pest management. $3^{\text {rd }}$ ed. Wiley, 161-162.

Larbat R. et al., 2015. Interrelated responses of tomato plants and the leaf miner Tuta absoluta to nitrogen supply. Plant Biol., 18, 495-504.

Leite G.L.D., Picanço M.,Azevedo A.A. \& Gonring A.H.R., 1999a. Efeito de tricomas, aleloquímicos e nutrientes na resistência de Lycopersicon hirsutum à traça-dotomateiro. Pesquisa Agropecuaria Bras., 34, 2059-2064.

Leite G.L.D., Picanco M.,Lucia T.M.C.D. \& Moreira M.D., 1999b. Role of canopy height in the resistance of Lycopersicon hirsutum f. glabratum to Tuta absoluta (Lep., Gelechiidae). J. Appl. Entomol., 123, 459-463. 
Leite G.L., Picanço M., Guedes R.N. \& Zanuncio J., 2001. Role of plant age in the resistance of Lycopersicon hirsutum f. glabratum to the tomato leafminer Tuta absoluta (Lepidoptera: Gelechiidae). Sci. Hortic., 89, 103-113.

Leite G.L.D., Picanço M., Jham G.N. \& Marquini F., 2004. Intensity of Tuta absoluta (Meyrick, 1917) (Lepidoptera: Gelechiidae) and Liriomyza spp. (Diptera: Agromyzidae) attacks on Lycopersicum esculentum Mill. leaves. Ciênc. Agrotecnol., 28, 42-48.

Mansour R. et al., 2018. Occurrence, biology, natural enemies and management of Tuta absoluta in Africa. Entomol. Generalis, 38, 83-112.

Miranda M.M.M., Picanço M., Zanuncio J.C. \& Guedes R.N.C., 1998. Ecological life table of Tuta absoluta (Meyrick) (Lepidoptera: Gelechiidae). Biocontrol Sci. Technol., 8, 597-606.

Mohamed E.S.I. et al., 2015. Host plants record for tomato leaf miner Tuta absoluta (Meyrick) in Sudan. EPPO Bull., 45, 108-111.

Negi S., Sharma P.L., Sharma K.C. \& Verma S.C., 2018. Effect of host plants on developmental and population parameters of invasive leafminer, Tuta absoluta (Meyrick) (Lepidoptera: Gelechiidae). Phytoparasitica, 46, 213-221.

Notz A.P., 1992. Distribution of eggs and larvae of Scrobipalpula absoluta in potato plants. Rev. Facultad Agron., 18, 425-432.

Oliveira F.A. et al., 2009. Resistance of 57 greenhousegrown accessions of Lycopersicon esculentum and three cultivars to Tuta absoluta (Meyrick) (Lepidoptera: Gelechiidae). Sci. Hortic., 119, 182-187.

Painter R., 1951. Insect resistance in crop plants. New York, NY, USA: The Macmillan Co.

Pereyra P.C. \& Sánchez N.E., 2006. Effect of two solanaceous plants on developmental and population parameters of the tomato leaf miner, Tuta absoluta (Meyrick) (Lepidoptera: Gelechiidae). Neotropical Entomol., 35, 671-676.

Portakaldali M., Öztemiz S. \& Kütük H., 2013. A new host plant for Tuta absoluta (Meyrick) (Lepidoptera: Gelechiidae) in Turkey. J. Entomol. Res. Soc., 15, 21-24.

Proffit M. et al., 2011. Attraction and oviposition of Tuta absoluta females in response to tomato leaf volatiles. J. Chem. Ecol., 37, 565-574.
Rostami E. et al., 2017. Life table parameters of the tomato leaf miner Tuta absoluta (Lepidoptera: Gelechiidae) on different tomato cultivars. J. Appl. Entomol., 141, 88-96.

Sadeghinasab F., Safavi S.A., Ghadamyari M. \& Hosseininaveh V., 2017. Biochemical characterization of digestive carbohydrates of the tomato leaf miner, Tuta absoluta (Lepidoptera: Gelechiidae) larvae in response to feeding on six tomato cultivars. J. Crop Prot., 6, 377 389.

Shahbaz M., Nouri-Ganbalani G. \& Naseri B., 2017. Comparative damage and digestive enzyme activity of Tuta absoluta (Meyrick) (Lepidoptera: Gelechiidae) on 12 tomato cultivars. Entomol. Res., 49, 401-408, doi.org/ 10.1111/1748-5967.12271

Silva D.B., Bueno V.H.P., Lins J.C. \& Van Lenteren J.C., 2015. Life history data and population growth of Tuta absoluta at constant and alternating temperatures on two tomato lines. Bull. Insectol., 68, 223-232.

Sohrabi F., Nooryazdan H., Gharati B. \& Saeidi Z., 2016a. Evaluation of ten tomato cultivars for resistance against tomato leaf miner, Tuta absoluta (Meyrick) (Lepidoptera: Gelechiidae) under field infestation conditions. Entomol. Generalis, 36, 163-175.

Sohrabi F., Nooryazdan H.R., Gharati B. \& Saeidi Z., 2016b. Plant resistance to the moth Tuta absoluta (Meyrick) (Lepidoptera: Gelechiidae) in tomato cultivars. Neotropical Entomol., 46, 203-209.

Torres J.B., Faria C.A., Evangelista W.S. \& Pratissoli D., 2001. Within-plant distribution of the leaf miner Tuta absoluta (Meyrick) immatures in processing tomatoes, with notes on plant phenology. Int. J. Pest Manage., 47, 173-178.

Tropea Garzia G., 2009. Physalis peruviana L. (Solanaceae), a host plant of Tuta absoluta in Italy. IOBC/WPRS Bull., 49, 231-232.

Verheggen F. \& Fontus R.B., 2019. First record of Tuta absoluta (Meyrick) (Lepidoptera: Gelechiidae) in Haiti. Entomol. Generalis, 38, 349-353.

Vitta N., Estay P. \& Chorbadjian R.A., 2016. Characterization of resistance expression in genotypes of Solanum section Lycopersicon against Tuta absoluta (Lepidoptera: Gelechiidae). Cienc. Investigacion Agrar., 43, 366-373.

(68 ref.) 